\title{
Food, Eating and Social Dynamics in the Retirement Community
}

\author{
Lisa M. Curch, Oneonta
}

\section{Introduction}

The study of the health behavior of elderly people is a relatively new and important area of research because of the impact that a host of behaviors exert on health and well-being. Recent research has shown that altering and maintaining healthy behaviors can influence morbidity and mortality even into advanced age (FrIES 2000; WILCOX \& KING 1999). Older adults in general appear to follow healthier lifestyles (BERKMAN \& BRESLOW 1983). However, WALKER (1997) observed that the heterogeneity of senior citizens extends to their health behaviors, and although many follow healthy lifestyles, many do not. Kaplan and Strawbridge (1994) remarked that the heterogeneity of the older adult population supports the importance of behavioral and social factors (including the physical environment) as they influence health in later life.

As for specific health behaviors, research has implicated dietary behaviors as very pertinent to the physical well-being of elderly people. Diet is a factor associated with leading causes of death, such as coronary heart disease, arteriosclerosis, stroke, diabetes, and some chronic diseases, such as osteoporosis (Institute of Medicine 2000; White \& Ham 1999). Obesity is a nutritional problem that affects elderly people, but nutritional deficiencies are also of much concern (Institute of Medicine 2000; White \& Ham 1999).

As observed by Amarantos, Martinez and Dwyer (2001) and Drewnowski and Evans (2001), good nutrition and dietary behaviors can also greatly impact an elder's quality of life. However, research commonly attempts to evaluate dietary practices in terms of the classic biomedical endpoints: mortality and morbidity. Lowering risks of mortality and illness are certainly important, especially since even a small change in morbidity can have a large impact on quality of life. Yet, as Amarantos et al. (2001) alternatively noted, quality of life is more than mortality and morbidity rates, contending that quality of life also involves life satisfaction and mental well-being. They pointed out that nutrition and dietary practices have not been included in influential quality of life domains. Drewnowski and Evans (2001) asserted that enjoyment of diet may be as important to quality of life as physical health indicators.

Social aspects of dietary behaviors are less often mentioned in the health behavior literature, yet they may also be very important for quality of life for older adults (Sidenvall, Nydahl \& Fuellstrom 2000). Bвомвасн (2001), for example, suggested that meals have an important role in structuring the day for elderly German women, and that social and cultural factors influence the kinds of food eaten and the timing of meals. Gender is an influential social factor affecting health behaviors. Research suggests that differences in health-related practices among men and women begin to appear at young ages (Leventhal 2000). Women have been subject to certain societal expectations and stereotypes regarding particular health behaviors (VerbRUGGe 1990); for instance, the female gender has traditionally been responsible for providing nourishment for others.

Environmental factors have received only limited attention as related to dietary behavior, although they apparently impact dietary actions and experiences as well. McIntosh and Shifflett (1984) found living alone had a negative effect on dietary quality for elders, as did Niewind, KRONDL and LAU (1988), but Horwath (1989) found that the effects of living arrangements were contingent on gender, uncovering an adverse effect for men living alone, but not for women living alone. Similarly, Schlettwein and BARCLAY (1995) found that European women living alone did not differ from women living with others in dietary intake and nutritional status.

Research has fairly recently begun to examine dietary and health behavior of elderly people in the context of age-segregated residential communities. Over the last twenty years, a number of studies have addressed food and eating issues in nursing homes (e.g. Alford 1986; Kayser-Jones 1996; KaYSER-Jones \& SChell 1997; Matthews 1987; Yen 1995). Studies regarding quality of life in assisted living facilities and satisfaction with the residence have consistently shown that food services and the dining experience rank as top factors (BALl et al. 2000; RAYNes 1998).

Others have described innovations and approaches to dining services in retirement communities, emphasizing how improved food and dining services can enhance enjoyment of meals and overall quality of life (Gilani 1995; Nickels 2000). Cluskey (2001a, 2001b) researched dining and food intake of residents in continuing care retirement communities (CCRCs), and reported that residents in the community site ate fairly well. The residents surveyed did not believe their intakes had changed as a result of residing in the community. Cluskey (2001a) also argued that CCRCs 
should offer the option of providing three meals a day, suggesting that doing so would result in improved food intake and ultimately contribute to the residents' ability to remain independent.

In GUBRIUM's (1997) ethnographic study of a nursing and residential home, he observed that residents divided the day into three parts, according to mealtimes, and that a great deal of the residents' discussions centered on dining and food. JACOBS (1975), in his description of a high-rise retirement complex, noted that residents devoted a good portion of their leisure time to food-related activities, such as clipping coupons, exchanging recipes, and discussing the day's menu with neighbors. KeIth Ross (1977) described food-related activities in her study of the French retirement community Les Floralies, particularly the social organizational aspects of the Dining Room. The arena for public contact was the Dining Room. It was the place where each resident daily saw all the other residents, and new residents met people.

Social and environmental aspects of dietary practices therefore appear to be significant for both the physical and psychosocial well-being of older adults. Yet much research and theory on health behaviors of adults in general has focused more on cognitive and psychological processes, such as motivation, beliefs, efficacy, and locus of control (BennetT \& Murphy 1997). This tendency is evident also in studies of older adults' health behaviors (e.g. GREMBowsKI et al. 1993; RAKowsKI \& HiCKeY 1980). The sociocultural and environmental aspects of health behavior generally, and of dietary behavior specifically, in later life have not been adequately addressed, despite the importance of such aspects. LuPTON (1996: 7) purports that a social science perspective on food and eating considers what it means in the context of a culture, and argues that the practices surrounding the foodways of people (food acquisition, preparation and consumption) may be governed by biological needs, but «these practices are then elaborated according to cultural mores».

The study in this paper attempted to ascertain types of social and environmental factors in a retirement community that are relevant to dietary behaviors of elders, especially as it affects older female residents (in recognition of traditional gender roles relating to food). The research site was Colonial Square (a pseudonym), an independent living retirement housing community in the heart of Kentucky, USA. Eighteen women were interviewed, and a guiding research question was: how does daily life at a retirement community structure current dietary behavior and related experiences? Using a life course perspective, it was conjectured that residence in a retirement community (particularly one which provides dining services) impacts both physical and social aspects of residents' food and eating practices and experiences, with the positive or negative direction of effects moderated by personal biography (e.g. personal health, established dietary behavior, earlier life experiences), social interaction (including social status, such as age, gender and marital status, and associated roles), and the physical and social environment of the retirement community.

This article contributes towards providing information on the dietary practices of the elderly and the influences thereon, data which to-date has been lacking It highlights a clear connection between social issues related to dietary behavior, such as gender, social interaction and environmental situations (which impact behavior itself as well as the social milieu for behavior). In accordance with LuPTON's (1996) contention, it was important here to further determine the culture and cultural mores of the retirement community, and to show how they impacted on residents' actions.

\section{Methods}

The overall design for this study utilized a qualitative research framework, and a constructivist approach, which allows study of the topic from the viewpoint of the participants. Such an approach has been used in prior studies on food and eating, and has been employed effectively (e.g. Devine et al. 1998).

The research took place in an independent living retirement community, for which the pseudonym Colonial Square is used. All participants also have pseudonyms. Colonial Square is situated on 20 acres in a metropolitan area of central Kentucky, USA (Map 1). There are about 205 residents, who are mostly white, educated and fairly affluent, and the women outnumber the men. Residents come from all over the United States, though many are from Kentucky.

Purposive sampling resulted in participants who varied by age and familial situations, operationalized as different marital statuses and marital histories. The total number of participants for the study was 18 . All were living independently, although two of them did receive some assistance from others (hired help) for personal care. The sample consisted entirely of white, older American women.

In-depth narrative interviewing was the main method of collecting data because of the method's capacity to elicit aspects of context, meaning and process in the responses of the participants. At the first meeting with a participant, the researcher began a general life history interview, using a life history interview guide developed for this study. After reviewing a par- 


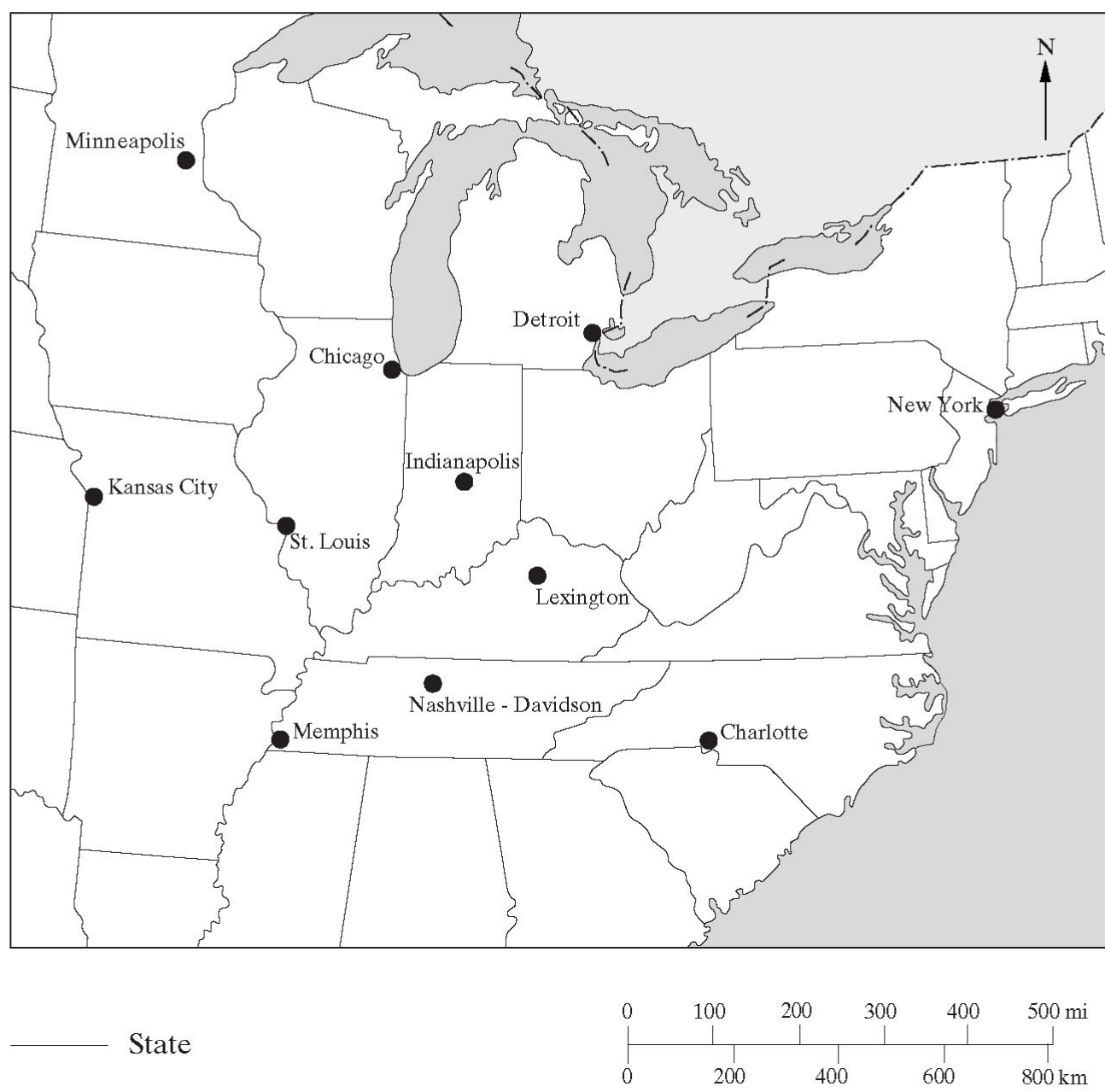

Map 1: Lexington, Kentucky, USA

Lexington, Kentucky, USA

Lexington, Kentucky, USA

Cartography: L. BAUMANN

ticipant's general life history, the researcher began a food history interview, in which the researcher elicited details about the participants' food and eating experiences over their lifetimes. A food history interview guide was also created specifically for this purpose. Devine et al.'s (1998) interview guide contributed to its development.

Other methods used in this research involved participant observation. This included taking meals in the dining room, attending a food committee meeting,informal conversations, and picture taking. During the period of interviewing and participant observation work, the researcher used opportunities available to spend additional time with the residents and staff at Colonial Square.

Basic descriptive statistical techniques were used to produce frequencies, averages, medians and modes for several characteristics of each participant, related to age, family, education, career, health, religion and prior residence. Open and focused coding generated an exhaustive list of themes that guided analysis, interpretation and writing.

After data collection was completed, thematic analysis was used to extract meaningful themes, patterns and topics. The generation of meaning from analysis involved clustering techniques and making contrasts and comparisons (Miles \& HuBerman 1994). Recurring themes were identified, and pieces of text were categorized (i.e. clustered) that related to various themes. However, identifying differences in data (data that cannot be clustered and grouped, or is a single instance of a theme) sharpened the analysis and helped to make sense of what appeared to be going on in the lives of the participants. 


\section{Results}

Participants ranged in age from 72 to 94 years; most were in their eighties. The majority $(56 \%)$ were widowed. One third of the participants were married and lived with their partners. One participant had been divorced for 21 years, and another was single, never married. All but two of the participants had children. All of the women were at least high school graduates. Most of them, 14 out of 18 women, pursued education beyond high school. All of the participants were retired and none were employed at the time of the study. Finally, the participants rated their health as fair to good. A few had conditions for which diet played a role in the management of the conditions, such as diabetes, diverticulosis, high blood pressure and high cholesterol.
The various factors affecting the women's dietary practices can be sorted into four categories, constituting different levels of influence, from individual factors to wider contexts of community policy and even world events.

\subsection{Ageing Factors}

Physical ageing affected the women in terms of getting to meals and social stigma. An issue for some of them, particularly the oldest participants, was the distance of the Dining Room from a number of the apartments. Because of the layout of the building (Figure 1), residents living at the end of the longer wing had quite a walk to the Dining Room and other common areas of Colonial Square. For Mrs. Stokes, this walk could be physically demanding, and she often had to stop to rest

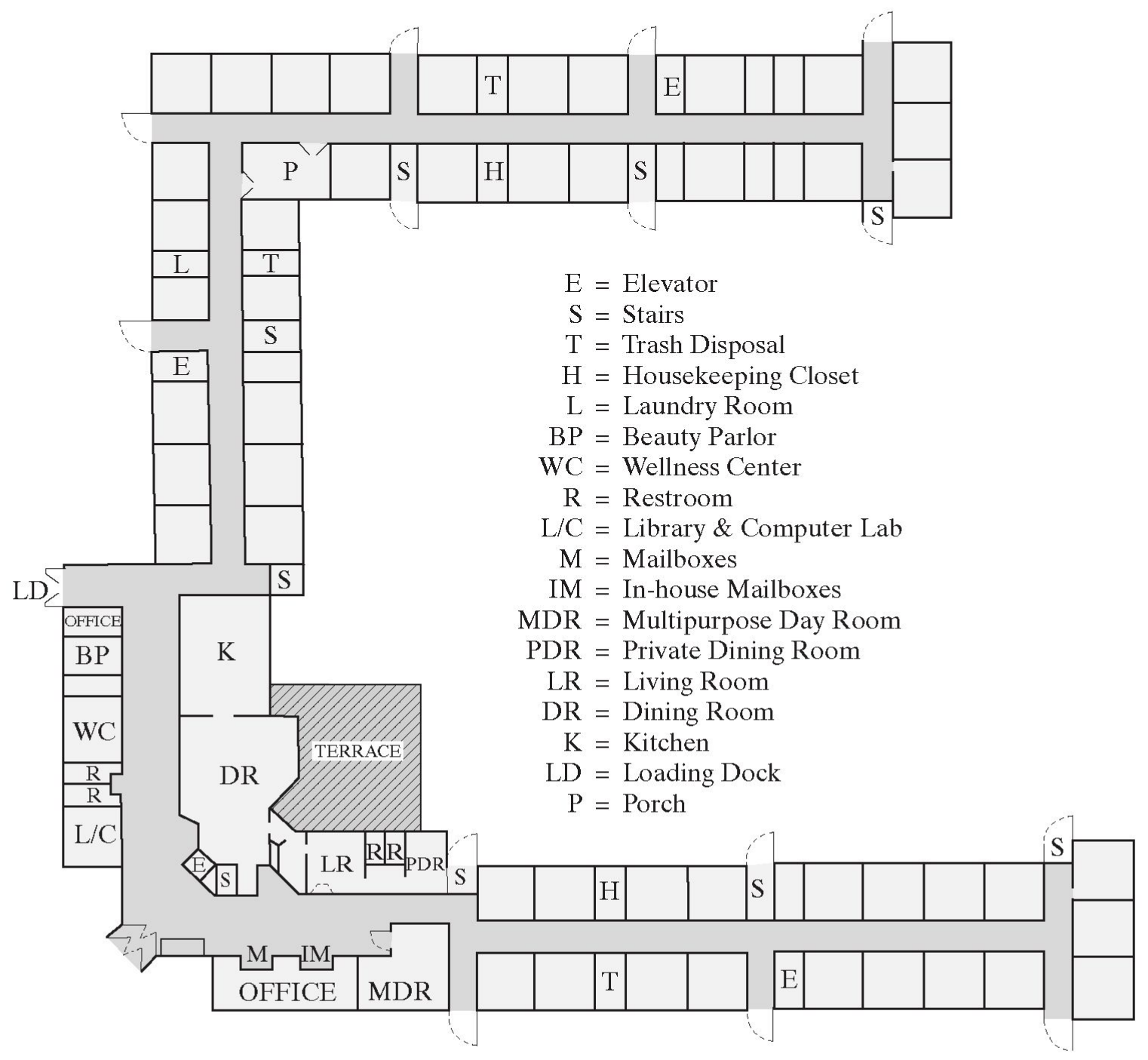

Figure 1: First floor of the retirement community Le rez-de-chaussée de la communauté de retraités Das Erdgeschoss der Altersresidenz Draft: L.M. CuRCH; graphics: L. BAUMANN 
on her way to the Dining Room. Mrs. Monroe used a self-propelled wheelchair, which made the journey to and from the Dining Room a tiring one.

Mrs. Randall brought up another mobility-related issue, assistive devices (such as walkers) in the Dining Room:

«They [other residents] were saying that it doesn't look elegant. With those things sitting around the tables. So through the years, they have resolved: park it here in the living room and get inside. Now there's some people who can't quite do that. There have been comments through the years, 〈It's beginning to look like a nursing home.> Well, those people, unfortunately, don't realize that some of those people when they came in here were walking around like everybody else. And this is the ageing process in this facility.»

Another resident raised this issue, but she was not as tolerant. She seemed to assume that people who needed such devices perhaps should not be residing in an independent living community, and implied that others did not want to see those sorts of things. Thus, it appeared that there was some social stigma for residents who exhibited frailty and required assistance with ambulation.

\subsection{Resident Interaction and Roles}

Social interaction was very important in terms of food and eating. Because the main meal was taken in the Dining Room, eating was a social event for the residents. Many participants stated how much they enjoyed the social aspect of eating in the Dining Room, particularly the widowed and single women. Similar to other widows, Mrs. Michaels found that after her husband died, eating alone was a big and difficult change, and it meant a lot to her to have people to eat with now. The Dining Room was the main place where residents visited with one another, and it was a place to make new friends (Figure 2).

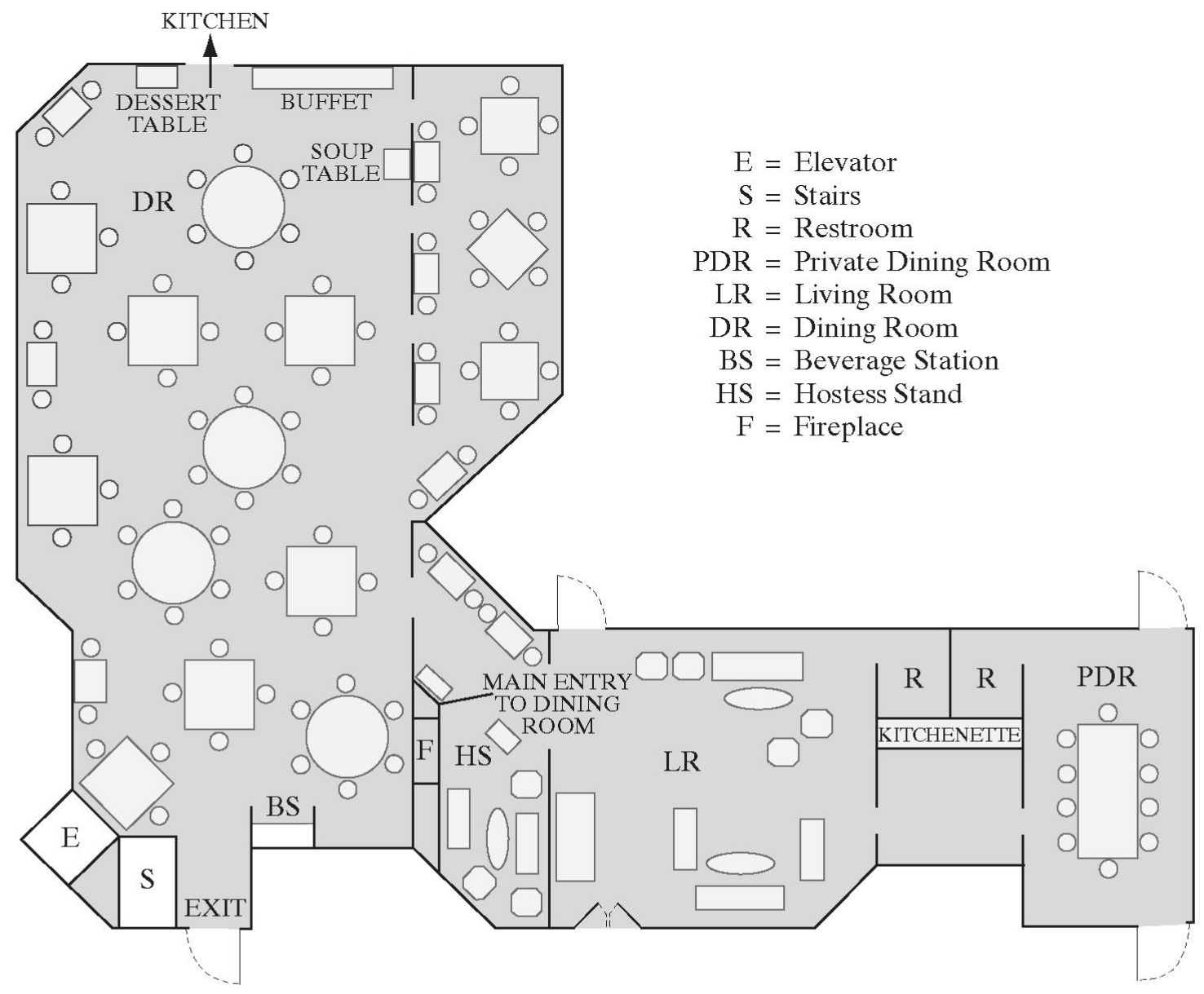

Figure 2: Dining room in the retirement community

Le réfectoire de la communauté de retraités

Der Speisesaal der Altersresidenz

Draft: L.M. CuRCH; graphics: L. BAUMANN 
Colonial Square had varied patterns of social arrangements at meal times. Over half of the women had another resident or a group of residents with whom they regularly ate. At least two of the women regularly met with different residents or groups for meals, depending on the meal or day of the week. For example, Mrs. Faust and her husband had a regular group they ate with at breakfast, but dined with different people each evening. Mrs. Donovan had a group she normally dined with during the week, but ate with a different group on the weekends. Five of the women stated their preference to mingle rather than be a part of any particular clique. Two participants had a certain table where they preferred to sit when they had a meal in the Dining Room, but the rest sat wherever they found a place or someone with whom they wished to dine.

More than a few participants referred to their role as a spouse when discussing dietary practices. For the women in the study who were still married, they continued in their role as the one mainly responsible for domestic food-related tasks. For many men of this generation, traditional gender roles dictated that it was mostly a woman's job to prepare food. Consistent with this expectation, the husbands did not cook beyond simple food preparation, such as getting cereals. Their wives often helped them along, buying or preparing food to have around for them. Two women acknowledged that the fact that meals were provided at Colonial Square was a factor in their decision to move, because they felt some security knowing that if anything would happen to them, their husbands would still be fed.

\subsection{The Retirement Community Environment: \\ The Dining Room, Apartments and Policies}

The general view of the Dining Room, and the meals served there, was overall positive. For the most part, the women felt that any deficiencies were relatively minor, and could be overlooked. Quite a few were happy enough to not have to cook and felt seriously complaining was not justified. Three women recognized that when they first moved to Colonial Square, it was such a novelty to not have to cook or worry about fixing dinner, and all the food seemed wonderful. But after being there a while, the food had become more institutional to them.

Many participants mentioned that they thought the Dining Room had a wide variety in food offerings, although a few felt that lately the menus had been somewhat repetitious. All but one of the participants were satisfied with the overall nutritional quality of the food available. Criticisms included too much heavy and high calorie food, too generous portions, and seasoning issues (too many spices/salt or too bland). How- ever, several appreciated attempts to offer more sugarfree, salt-free and fat-free options.

The latest news about the Dining Room always got around. All but one of the women made it a point to state that oatmeal was now offered at breakfast, and how well that had gone over with the residents. Almost all also reported that there was a new Chinese cook, and although their reactions to the Chinese dishes have been mixed, they seemed to appreciate that the kitchen tried something new. Other fairly recent additions to the menus included more contemporary entrees, such as sandwich wraps. These too have had a mixed reception by the women, as many of them preferred the standard «well-balanced» meal of meat, potatoes and vegetables (the type of meal that most of them had always known).

Meals eaten in the private apartments were generally simple and light, and prepared in small amounts, with an emphasis on quick and easy. Soup, sometimes homemade, but mostly canned, was quite often lunch or dinner, and might be accompanied by cheese and crackers, a salad or a sandwich. Four women kept frozen or prepackaged dinners for quick meals. A couple of the participants kept very little food in their apartments, such as Mrs. Richardson (though her freezer is full of ice cream); all except one of the other participants stored a moderate amount of food.

The apartment kitchens all have a full-size refrigerator, a full-size oven with stovetop, and a dishwasher. The women generally brought additional appliances with them; all the women had a microwave. Over half of the women rarely used their ovens, if they turned them on at all. At least three of the participants used their ovens to store things, mainly pots and pans. This caused Mrs. Adams, who used oven space for storage, to be less likely to use the oven, because she did not want to bother emptying and reloading it. One participant related that she knew of residents who used their dishwasher to store things. Many of the women gave away most of their cookware, retaining only what they needed, such as a couple of pots and pans. For several women, this divesture of cooking items came after they moved. At least a third of the women expressed that they felt they had brought more than they needed to Colonial Square.

Particular community policies that affected the residents' dietary practices were the Dining Room hours, the Dining Room dress code, and the policy on taking food from the Dining Room. Regarding meal hours, the times could be problematic. At least three of the participants were not on any type of meal schedule before moving to Colonial Square, and found it trying to adjust to regular meal times. 
The perceived needs of the staff, particularly the servers, to some extent influenced the time when a few participants went to dinner:

«I go about 5:30 now. And that's too early. I don't like it. But I go. The little school girls - our waiters and waitresses, the schoolchildren, and they want to get through and get away, you know, so we go earlier and earlier so that they can get through and get away...» (Mrs. Provost)

There was the feeling among those who preferred to eat later that they should not go to the Dining Room too late, although no one said that any of the servers had explicitly expressed wanting to go home as early as possible. It still seemed that residents felt a bit rushed when they went later, even though they should have been able to receive service until 7:00 p.m.

The dress code for the Dining Room was established by residents many years ago. Nearly all of the participants stated that they were satisfied with the dress code. About a third of the women remarked that lately many residents had not been following the dress code as closely as it should be. A small number of women thought that it was quite important to have a dress code, and that it was good for people to make an effort to look nice for meals. Mrs. Michaels, however, did not attach as much importance to the dress code:

«I don't feel that it's that necessary... I think it's harder for older people to get dressed. You get dressed once for the daytime, that's about as much as you're going to - you know, it's hard to get dressed. When you have arthritis and all these ailments that we all get. I know by the time I get dressed, I'm tired.»

Another factor that may have affected how closely the dress code was followed were the activities of the residents. Mrs. Randall sometimes left right after dinner for bridge club; others also had evening activities that did not require dressing quite so nicely.

An issue brought up by several women was taking food from the Dining Room. The policy was that no food could be taken from the Dining Room, with the exception of desserts in a container provided by the resident. Mrs. Faust found fault with this policy:

«If they bring you too much food and you can't eat it, you can't bring it up to your room.... And if you have ham or something that's very - such that could be used for lunch, I don't see any reason why you couldn't bring that back. It's going to be thrown out. It doesn't make any sense to me.»

Mrs. Faust's thrifty side found the policy to be irrational. She revealed a loophole in the policy; she sometimes would ask for a banana for dessert and bring it home. Some residents deliberately violated the policy by smuggling food out of the Dining Room.

\subsection{Economic and Political Factors}

Finally, two women mentioned larger political and economic forces as a perceived influence on dietary practices. Mrs. Faust took an economic approach, as she explained that availability and cost of food had always influenced her. Recently, current events played a role in dietary practices as reported by Mrs. Stokes, whose concern about bioterrorism became personal for her. She explained:

«Well, I'm worried about it [anthrax] getting in the food.

Because a lot of our food comes from out of country... So

I wash everything real good, grapes and all that.»

\section{Discussion}

The narratives of these older women illustrated the importance of social and residential situations as influences on dietary practices. The dietary experiences of the participants during their residence at Colonial Square demonstrated that a move to a retirement community, particularly one where dining services were available, affected the food and eating experiences of the women and their dietary behavior. The findings suggest that the ways in which the transition and the new social and environmental context affected the women depended on previous life experiences, and then their particular experiences in that environment.

The participants' dietary practices can be interpreted in terms of how the community both liberated and constrained their dietary actions. Several structural factors of the Colonial Square environment produced new liberations (or opportunities) for many of the women, which included freedom from food-related responsibilities and family members' preferences, food security, and social interaction opportunities. However, some structural factors of life at Colonial Square also constrained the participants in terms of a lack control over when and what they would eat, getting to meals, and social pressure (e.g. peer pressure to follow group norms).

A focus on living alone versus not living alone, which some studies have used (e.g. McIntosh and SHIFFLETT 1989), would be too narrow to apply to the women of this study. Although some of them live alone, they still dine with others at least once a day, and have social interaction and relations with others that have influenced them. Living alone might have fostered more reliance on convenience and frozen foods than if they lived with someone, but the community environment and their social network constitute a broader context that is important to take into account when examining the effects of living arrangements on dietary behavior of these older women. It also could be that gender made a difference, as Horwath (1989) contended and in support of SCHLETTWEIN and BARCLAY's (1995) conclusions. 
Meals structured the day for the participants as it did for those in Gubrium's (1997) and BROMBACH's (2001) studies. The women created meal schedules based on what they planned to have as their main meal (either lunch or dinner) and when they were able to have their main meal (based on the community's dining hours), incorporating their preferences for times to the extent that they could. Finally, similar to Keтrн Ross' (1977) research, the Dining Room was a central arena for social contact.

\section{Conclusions}

A number of key elements emerging from this research would benefit from more focused study. There was indirect evidence suggesting important gender differences. The roles, interactions and contexts for men may differentially influence their dietary behavior, and future studies should consider male perspectives. It is also apparent that a life course transition such as a residential move can have profound implications to the food practices of the elderly. Benefits and limitations in residential settings deserve further exploration as the senior housing market continues to expand.

Prospective studies which interview an older adult before and after a residential transition could be valuable for revealing what aspects of the transitions do and do not cause dietary change. Some concepts uncovered in this research that may be suitable for exploration by survey methods include quality aspects of meals rather than quantity (e.g. heavy versus light meals), strategies used for food preparation, and the notion of constraints and opportunities related to food and eating in retirement communities.

The research additionally has implications for practice. More specifically, collecting dietary histories and narratives from incoming residents might help retirement communities better serve residents. The identification of features that are perceived as constraining or facilitating would allow communities to work on rendering the residential context as facilitative as possible with respect to food and dining services. Dietary narratives and improvements to systems ultimately would enhance quality of life.

\section{Literature cited}

Alford, D.M. (1986): Behavioral response of the institutionalized elderly to eating and food services. - In: Nursing Homes 35: 20-24.

Amarantos, E., Martinez, A. \& J. Dwyer (2001): Nutrition and quality of life in older adults. - In: Journals of Gerontology: Biological Sciences and Medical Sciences 56A: 54-64.
Ball, M.M., Whittington, F.J., Perkins, M.M., Patterson, V.L., Hollingsworth, C., King, S.V.\& B.L. Combs (2000): Quality of life in assisted living facilities: Viewpoints of residents. - In: Journal of Applied Gerontology 19: 304-325.

BennetT, P. \& S. MurPhy (1997): Psychology and Health Promotion. - Philadelphia: Open University Press.

Berkman, L. \& L. BresLow (1983): Health and Ways of Living: The Alameda County Study. - New York: Oxford University Press.

Brombach, C.H. (2001): The EVA-Study: Meal patterns of women over 65 years. - In: Journal of Nutrition, Health and Aging 5:263-265.

Cluskey, M. (2001a): Offering three-meal options in continuing care retirement communities may improve intake of residents. - In: Journal of Nutrition for the Elderly 20: 57-62.

Cluskey, M. (2001b): Preliminary investigation of the food intake patterns and beliefs among independent living elderly residents in a continuing care retirement community. - In: Journal of Nutrition for the Elderly 20: 29-38.

Devine, C.M., Connors, M., Bisogni, C.A. \& J. Sobal (1998): Life-course influences on fruit and vegetable trajectories: Qualitative analysis of food choices. - In: Journal of Nutrition Education 30: 361-370.

DrewnowsKi, A. \& W.J. Evans (2001): Nutrition, physical activity, and quality of life in adults: Summary. In: Journals of Gerontology: Biological Sciences and Medical Sciences 56A: 89-94.

FrIes, J.F. (2000): Compression of morbidity in the elderly. - In: Vaccine 18: 1584-1589.

GILANI, S. (1995): Tempting the tastes of seniors. In: Spectrum: National Association for Senior Living Industries 9: 20-22.

Grembowski, D., Patrick, D., Durham, M., Beresford, S., KaY, E. \& J. Неснт (1993): Self-efficacy and health behaviors of older adults. - In: Journal of Health and Social Behavior 34: 89-104.

Gubrium, J.F. (1997): Living and Dying at Murray Manor. - Charlottesville, VA: University Press of Virginia.

Horwath, C.C. (1989): Marriage and diet in elderly Australians: Results from a large random survey. - In: Journal of Human Nutrition and Dietetics 2: 185-193.

Institute of Medicine (2000): The Role of Nutrition in Maintaining Health in the Nation's Elderly. - Washington D.C.: National Academy Press.

JACOBs, J. (1975): Older Persons and Retirement Communities: Case Studies in Gerontology. - Springfield, IL: Charles C. Thomas.

Kaplan, G.A. \& W.J. StRawbridge (1994): Behavioral and social factors in healthy aging. - In: ABELEs, R.P., Gift, H.C. \& M.G. Ory (eds): Aging and Quality of Life. - New York: Springer: 57-78.

KaYSER-Jones, J. (1996): Mealtime in nursing homes: 
The importance of individualized care. - In: Journal of Gerontological Nursing 22: 26-31.

KaYser-Jones, J. \& E.S. Schell (1997): Staffing and mealtime experience of nursing home residents on a special care unit. - In: American Journal of Alzheimer's Disease 12: 67-72.

Keith Ross, J. (1977): Old People, New Lives: Community Creation in a Retirement Residence. - Chicago: University of Chicago Press.

Leventhal, E. (2000): Aging women, getting older, getting better? - In: Manuck, S.B., JENnings, R., Rabin, B.S. \& A. Baum (eds): Behavior, Health and Aging. Mahwah, NJ: Lawrence Erlbaum Associates: 27-42.

Lupton, D. (1996): Food, the Body and the Self. London: Sage.

Matrhews, L.E. (1987): Perceptions of elderly residents - geriatric not pediatric. - In: Journal of Nutrition for the Elderly 6: 57-60.

McIntosh, W.A. \& P.A. Shifflett (1984): The influence of social support systems on dietary intake of the elderly. - In: Journal of Nutrition of the Elderly 4:5-18. Miles, M.B. \& A.M. Huberman (1994): Qualitative Data Analysis: An Expanded Sourcebook. $-2^{\text {nd }}$ edition, Thousand Oaks, CA: Sage.

Nickels, A. (2000): Eating habits. - In: Assisted Living Today 7: 55-56.

Niewind, A.C., Krondu, M. \& D. LaU (1988): Relative impact of selected factors on food choices of elderly individuals. - In: Canadian Journal on Aging 7:32-47.

Rakowski, W. \& T. Hickey (1980): Late life health behavior: Integrating health beliefs and temporal perspectives. - In: Research on Aging 2: 283-308.

RAYNES, N.V. (1998): Involving residents in quality specification. - In: Ageing and Society 18: 65-78.

Schlettwein, G.D. \& D. Barclay (1995): Dietary habits and attitudes in healthy elderly. - In: DALL, J.L.C., Ermin, M., Herrling, P.L., Meier-Ruge, W. \& H.B. StAHELIN (eds): Adaptations in Aging. - London: Academic Press: 253-264.

Sidenvall, B., Nydahl, M. \& C. Fuellastrom (2000): The meal as a gift - the meaning of cooking among retired women. - In: Journal of Applied Gerontology 19: 405-423.

WALKeR, S.N. (1997): Promoting healthy aging. - In: Ferraro, K. (ed.): Gerontology: Perspectives and Issues. $-2^{\text {nd }}$ edition, New York: Springer: 305-323.

White, J. \& R.J. HAм (1999): Older adults. - In: MoRRISON, G. \& L. HARK (eds): Medical Nutrition and Disease. $-2^{\text {nd }}$ edition, Malden, MA: Blackwell Science: 134-155.

WiLcox, S. \& A.C. KING (1999): Health behaviors and aging. - In: HAZZARD, W.R., Blass, J.P., ETTINGER, W.H., Halter, J.B. \& J.G. Ouslander (eds): Principles of Geriatric Medicine and Gerontology. $-4^{\text {th }}$ edition, New York: McGraw-Hill: 287-302.

YEN, P.K. (1995): What elders think about food. - In: Geriatric Nursing 16:187-188.

\section{Summary: Food, Eating and Social Dynamics in the Retirement Community}

Research has shown that positive dietary practices play a role in preventing morbidity, delaying mortality, and enhancing quality of life. Not as well researched are the dietary behaviors of elderly women. The purpose of this study was to examine how the physical and social environment of a retirement community without special care ammenities shapes dietary practices among older women. In-depth narrative interviews with 18 female residents allowed insight into their dietary experiences. The consequent analysis identified four levels of influence: 1) ageing factors; 2) resident interaction and roles; 3 ) the retirement community environment; and 4) economic and political factors. Findings were interpreted in terms of social experiences and structural characteristics of the retirement community that constrain or facilitate dietary practices. These findings provide a better understanding of elderly women's dietary behavior and have implications on quality of life issues for residents of retirement communities.

\section{Résumé: La nourriture, l'alimentation et les dyna- miques sociales dans les communautés de retraités} Des habitudes alimentaires positives jouent un rôle dans la prévention de la maladie, l'éloignement de la mort et l'amélioration de la qualité de vie en général. Une recherche approfondie demeure toutefois nécessaire en ce qui concerne les habitudes alimentaires des femmes âgées. Une étude comme celle-ci a pour but de découvrir de quelle façon l'environnement physique et social d'une communauté de retraités non dépendants influence les habitudes alimentaires de femmes âgées. Des entretiens approfondis avec 18 résidentes ont mis en relief l'expérience alimentaire de ces personnes. L'analyse faite a fait apparaître quatre niveaux d'influence: 1) les facteurs de vieillissement, 2) l'interaction et les rôles des résidents, 3) l'environnement d'une communauté de retraités, 4) les facteurs économiques et politiques. Les résultats ont été interprétés en fonction d'expériences sociales et caractéristiques structurales de la communauté de retraite qui contraignent ou facilitent des habitudes alimentaires. Ces résultats obtenus permettent en outre une meilleure compréhension de la conduite alimentaire des femmes âgées. Ils mettent aussi l'accent sur la thématique de la qualité de vie des résidents des communautés de retraités.

\section{Zusammenfassung: Ernährung, Essgewohnheiten und die soziale Dynamik in Altersresidenzen}

Gesunde Ernährunspraktiken spielen eine wichtige Rolle in Hinsicht auf die Prävention von Krankheiten, die Verzögerung von Todesfällen und die Steigerung der allgemeinen Lebensqualität. Jedoch mangelt es an einer gründlichen Untersuchung hinsichtlich 
der Essgewohnheiten älterer Frauen. Ziel der Studie war es herauszufinden, wie die körperliche Verfassung und die soziale Umgebung einer unabhängig lebenden Pensionärskommune die Ernährungspraktiken älterer Frauen beeinflussen. Tiefeninterviews mit achtzehn Bewohnerinnen einer Altersresidenz erfassten deren Erfahrungen mit ihrer Ernährung. Die Analyse brachte vier Ebenen der Beeinflussung zum Vorschein: 1) Altersfaktoren, 2) die Interaktion und Rollen der Bewohner, 3) die Umgebung des Altersheims und 4) ökonomische und politische Faktoren. Die Resultate wurden mit Rücksicht auf soziale Erfahrungen und strukturelle Charakteristika der Altersheime interpretiert, welche bestimmte Ernährungsgewohnheiten entweder blockieren oder fördern. Die Resultate liefern einen Beitrag zum Verständnis der Essgewohnheiten älterer Frauen, welche die Lebensqualität von Altersheimbewohnern beeinflussen.

\section{Teaching of Geography - relevant questions}

- What issues might be raised by the physical ageing of residents in a retirement community, pertaining to dining and other eating-related experiences of residents?
- In what ways can social interaction in the retirement community affect the dietary behavior and eating experiences of residents?

- In what ways can various environmental aspects of the retirement community affect the dietary behavior and eating experiences of residents?

- How does the retirement community both enhance and hinder residents' dietary actions?

Lisa M. Curch, Ph.D., Assistant Professor, Department of Sociology, 418 Fitzelle Hall, State University of New York - College at Oneonta, Oneonta, NY 13820, U.S.A.

e-mail: curchlm@oneonta.edu

Manuskripteingang/received/manuscrit entré le 27.3.2004

Annahme zum Druck/accepted for publication/accepté pour l'impression: 1.12.2004 